\title{
The Impact of Training \& Development on Work Engagement: A Study in the Banking Sector
}

\author{
Chovarda, Maria \\ School of Economics, Business Administration \& Legal Studies, \\ International Hellenic University, \\ 14th km Thessaloniki - N.Moudania, 57001 Thermi, Greece \\ Theriou, Georgios (Corresponding author) \\ School of Economics and Business, Management Science and Technology, \\ International Hellenic University, Agios Loukas 65404 Kavala, Greece
}

Received: Jan. 19, 2021 Accepted: Feb. 7, 2021 Online published: Feb. 23, 2021

doi:10.5296/ijhrs.v11i1.18343

URL: https://doi.org/10.5296/ijhrs.v11i1.18343

\begin{abstract}
Employees play a crucial role in delivery of service quality and retention of satisfied and loyal customers. Of the various factors that contribute towards this end, work engagement among employees has gained a great deal of interest from both practitioners and academics in the fields of business, human resource development, and organizational psychology, based on the perspective that engaged employees are likely to display high quality performance in the workplace. Meanwhile, Training and Development (T\&D) practices are considered to contribute to the employees' engagement in their work environment. This paper examines the potential impact of Perceived Training Opportunities (PTO) and Perceived Investment in Employee Development (PIED) on work engagement. A research model has been developed and empirically tested, using primary data from a survey of 185 bank employees working in Greece. Empirical results reveal a strong relationship between PTO and PIED with work engagement. Banks should invest in training and development opportunities as a means to enhance work engagement and gain a competitive edge in delivering high quality services to the customers.
\end{abstract}

Keywords: work engagement, perceived training opportunities, perceived investment in employee development, bank employees, banking sector, human resource management 


\section{Introduction}

Work engagement is usually related with positive business results across all types of organizations (Lee, Kwon \& Cho, 2016). Despite that, the results of global Gallup surveys have shown that most employees, regardless of the organizational type, are not fully engaged in their job (Sweetman \& Luthans, 2010). Meanwhile, the banking industry seems to face a lot of work engagement challenges (e.g. Amigo, Asensio, Menéndez, Redondo \& Ledesma, 2014; CIPD 2013), as it is operating in an extremely competitive environment. Banks, as service organizations are knowledge-intensive and therefore the efficiency of human resources practices and the engagement of the employees is very important.

Work engagement has gained increased attention in the past few years in research related to professional development, in keeping with the trend of discussing positive aspects of organizational behavior (Bakker \& Leiter, 2010). According to Truss, Alfes, Delbridge, Shantz and Soane (2013), this increasing attention of engagement research studies shows the growing importance of the human capital in business. Therefore, in order to encourage employees' work engagement, banks must focus on providing a supportive work environment, keeping them energetic, inspired and concentrated. By equipping them with ongoing training programs, and development opportunities within the corporation, banks may enhance desired levels of work engagement.

According to Truitt (2011), organizations need to enhance the knowledge base and abilities of their employees. In general, Training \& Development (T\&D) practices allow businesses to compete, innovate, produce, improve service and reach objectives (Salas, Tannenbaum, Kraiger \& Smith-Jentsch, 2012). Xanthopoulou, Bakker, Demerouti and Schaufeli (2009) argue that employees working in a resourceful work environment (e.g. characterized by feedback and support) are likely to feel optimistic and to believe that they are able to achieve their work objectives. Empirical research shows that training perceptions are directly linked with engagement (Salanova, Agut, \& Peiró, 2005), and perceptions of HR practices, including training and development, are indirectly linked with performance via engagement (Alfes, Shantz, Truss, \& Soane, 2013). Researchers argue (Kehoe \& Wright, 2013; Nishii, Lepak, \& Schneider, 2008) that in order to examine the effect of any HRM practice on employee behavior researchers should focus on the perception of these practices, rather than relying on reports of the intentions behind these practices as descripted by HRM professionals.

Until now relatively few studies have concentrated on individual-level effects of HRM practices (Alfes et al., 2013), and so this study is focused on how employees' perceptions of $T \& D$ practices are related to positive employee outcomes. Within this context, the present empirical study aims to examine the relationship between T\&D activities and work engagement in the Greek banking sector. In specific, this study empirical tests the potential impact of Perceived Training Opportunities (PTO) and Perceived Investment in Employee Development (PIED) on work engagement. 


\section{Literature Review and Hypotheses}

\subsection{Work Engagement}

Work engagement is considered one of the major factors of productivity and performance (Gruman \& Saks, 2011). Work engagement is defined as "a positive, fulfilling, and work-related state of mind that is characterized by vigor, dedication, and absorption" (Schaufeli, Martinez, Pinto, Salanova, \& Bakker, 2002). Employees will be productive and perform well in the company when they are really engaged in the work. This means that the employee enjoys the work, is committed to the work and is more efficient and involved in the work (Schaufeli \& Bakker, 2004). In addition, conservation of resources (COR) theory has been used to analyze antecedents of work engagement (e.g. Mauno, Kinnunen, \& Ruokolainen, 2007). T\&D programs can be viewed as an organizational resource (Wheeler, Halbesleben \& Shanine, 2013) and are therefore likely to impact employees' energy levels (i.e., increasing work engagement).

\subsection{Training}

Training can be defined as "the systematic acquisition of knowledge, skills and attitudes that together lead to improved performance in a specific environment" (Salas, Wilson, Priest, \& Guthrie, 2006). According to Grossman \& Salas (2011) this term refers to what employees need to know, what they need to do and what they need to feel in order to successfully perform their responsibilities. Luthans, Avey, Avolio and Peterson, (2010) indicate that employee training is an important HR dimension to impact employee work outcomes and behaviors. Pate, Martin, and Staines, (2000) argue that employees no longer expect a job for life but rather training and development opportunities that increase their future employability.

Many authors argue that the benefits of employee training are well documented (Sommerville, 2007), including improved employee skills and behaviors (Treven, 2003) and results like improved employee performance (Brown, 1994) and productivity (Hughey \& Mussnug, 1997). Similarly, Sujatha, Chitra, Poonguzhali and Jahira Parveen (2020) argue that training and development programs have become crucial for the banking sector as they improve the skills and attitude of both employee and employers.

In their study, Demerouti \& Cropanzano (2010) proved that training helps employees to develop skills and competencies that are important for the organizational performance. Salas et al. (2006) emphasized how training can lead to improved work quality, increased motivation and higher morale, leading towards a competitive advantage.

\subsubsection{Perceived Training Opportunities}

Based on social exchange theory, employees who perceive that their organization provides adequate and applicable training opportunities might be less willing to leave their organization, as they feel obliged to reciprocate the offer provided (Benson, Finegold, \& Mohrman, 2004). So, Training opportunities are considered useful in making the employees feel that their employer cares about them and their well-being, in terms of having opportunities to develop. Moreover, Kuvaas (2008) in his study identified a negative 
relationship between perception of developmental HR practices (including training opportunities) and turnover intention.

Based on Kahn's (1990) psychological conditions, Gruman \& Saks (2011) believe that training is especially important for offering resources that will make employees feel available to actively engage in their role. In Salanova et al.'s (2005) study, training was an important resource that was positively related to engagement. Similarly, Crawford, LePine, and Rich, (2010) proved that organizations which prefer to provide extensive T\&D opportunities to their employees, achieve higher levels of work engagement among their staff.

On the basis of above theoretical and empirical studies, the following hypothesis is proposed:

H1. There is a positive relationship between perceived training opportunities and work engagement.

\subsection{Employee Development}

Although the terms 'training' and 'development' are often used interchangeably, they are not synonymous. Training typically focuses on equipping employees with specific skills and knowledge or helping the correct deficiencies in their performance. On the other hand, development has a long-term perspective and is closely related to the professional growth of individuals as it focuses on providing employees with the skills and abilities the organization will need in the future (Noe, 2013; Gomez-Mejia, Balkin, \& Cardy, 2012). According to McCauley \& Hezlett, (2001, p.314) employee development involves "the expansion of an individual's capacity to function effectively in his or her present or future job and work organization". The general belief in the literature has been that development programs will produce employees capable of fulfilling human capital needs (Dachner et al., 2019).

Lee \& Bruvold (2003) argue that investing in employee development is vital in maintaining and developing the skills, knowledge and abilities of both individual employees and the organization as a whole. As a result, when organizations invest in their employees, employees tend to reciprocate in positive ways (Cropanzano \& Mitchell, 2005) and they become prosocially motivated, specifically, they desire to expend effort to benefit the organization (Kuvaas \& Dysvik, 2009). Also, employee development increases employees' perceptions of opportunities in the labour market (i.e. perceived employability), which may enhance their turnover intention (Nelissen, Forrier, \& Verbruggen, 2016).

Consequently, organizations that provide developmental opportunities to their staff, tend to have hard work, skilled, and target oriented employees (Ling, Qing, \& Shen, 2014). According to Rahman \& Nas (2013) development is related with maintaining individual and organizational competencies and employees perceive organizational efforts towards skill development as a positive investment by the organization into them.

\subsubsection{Perceived Investment in Employee Development}

A number of studies have focused on Perceived Investment in Employee Development (PIED) because of its positive effect on both organizational and individual level (Dysvik, Kuvaas, \& Buch, 2016). PIED refers to employees' assessment of their organizations' commitment to 
employees' personal and professional growth by helping them learn to identify and obtain new skills and competencies, either within or outside these organizations (Lee \& Bruvold, 2003). Therefore, PIED (according to social exchange theory) may increase organizational effectiveness as motivated employees can be expected to invest greater effort towards the organization (Wayne et al., 1997; Kuvvas \& Dysvik, 2009).

Xanthopoulou et al. (2009) in their study reported a positive association between HRD practices and work engagement. Similarly, Saks (2006) showed that job resources as professional development was related positively to work engagement, suggesting that employees will repay their organization for the resources they receive with increased levels of engagement. PIED's effect on work engagement for workers with nonstandard work contracts, is also demonstrated in research. Jha, Pandey and Varkkey, (2019) in their research findings in India report that PIED is positively associated with work engagement of liquid knowledge workers. On the basis of above theoretical and empirical studies, the following hypothesis is proposed:

H2. There is a positive relationship between perceived investment in employee development and work engagement.

\subsection{Proposed Research Model}

Following the previous discussion, the research model is presented in Figure 1. According to our proposed model positive perceptions of training opportunities and employee development increase employees' work engagement, respectively. As pinpointed above, relatively few studies concentrate on individual experiences of HRM practices. Moreover, to the best of the researcher's knowledge, such a conceptual framework, has never been previously examined in the banking sector.

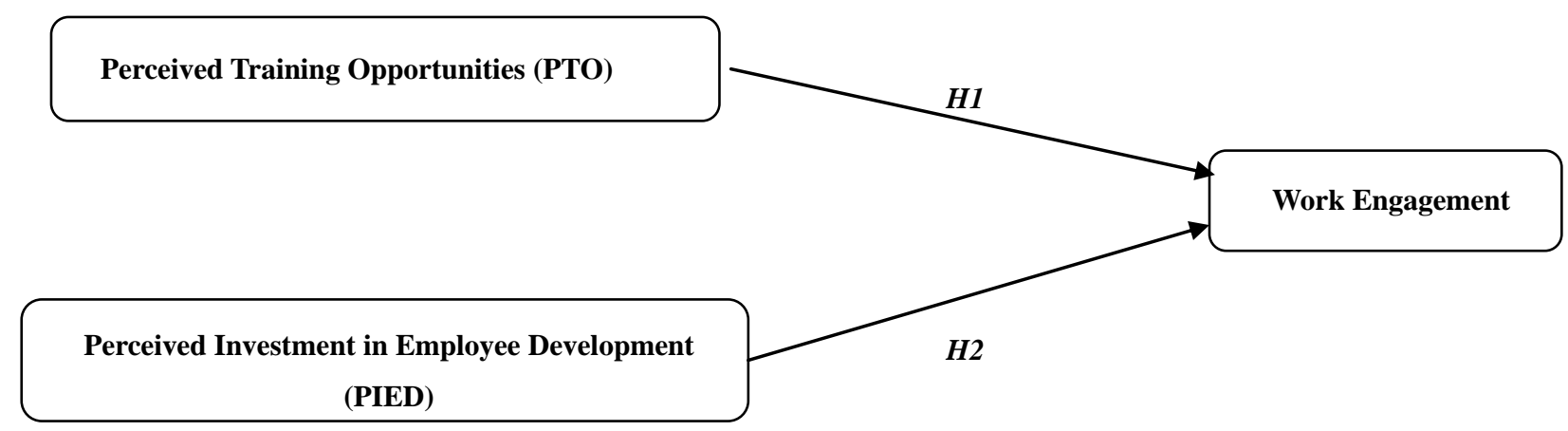

Figure 1. The proposed conceptual framework of the study

\section{Method}

In this research a quantitative approach was used in order to empirically test the proposed research model. Therefore, a structured questionnaire was developed and addressed to a number of employees working in Greek banks.

The questionnaire was created based on items adopted from previous relevant studies of the field. 


\section{Macrothink}

International Journal of Human Resource Studies

ISSN 2162-3058

2021, Vol. 11, No. 1

In particular, Perceived Training Opportunities (PTO) was measured by 4 items adopted from Dysvik \& Kuvaas (2008) addressing employees' evaluation of their training opportunities (e.g. satisfaction and adequacy). Perception of investment in employees' development (PIED) was measured by a 9-item scale adapted from Lee \& Bruvold's (2003) study. All items were on a 5-point Likert response scale ranging from 1 (strongly disagree) to 5 (strongly agree).

Work engagement was measured using the shortened version of the Work Engagement Scale (WES) created by Schaufeli \& Bakker (2004). This scale includes the three constituting aspects of work engagement: vigor, dedication, and absorption.

A 7-point Likert scale is used with categories related to feelings about the respondent's job: 0 (never), 1 (almost never), 2 (rarely), 3 (sometimes), 4 (often), 5 (very often) and 6 (always). Finally, the questions were translated to Greek and questionnaire items were reviewed and (slightly) modified by three academics. Description of each item is presented in the Appendix.

Table 1 demonstrates the three (3) factors measured in this research, the items used for their measurement and the studies from which they were adapted.

Table 1. Factor measurement

\begin{tabular}{|c|c|c|}
\hline Variables & $\begin{array}{l}\text { Number } \\
\text { of items }\end{array}$ & Sources \\
\hline $\begin{array}{l}\text { Perceived } \\
\text { Training } \\
\text { Opportunities } \\
\text { (PTO) }\end{array}$ & 4 & $\begin{array}{c}\text { Dysvik \& } \\
\text { Kuvaas } \\
(2008)\end{array}$ \\
\hline $\begin{array}{l}\text { Perceived } \\
\text { Investment in } \\
\text { Employee } \\
\text { Development } \\
\text { (PIED) }\end{array}$ & 9 & $\begin{array}{c}\text { Lee \& } \\
\text { Bruvold } \\
(2003)\end{array}$ \\
\hline $\begin{array}{l}\text { Work } \\
\text { engagement }\end{array}$ & 9 & \multirow{4}{*}{$\begin{array}{c}\text { Schaufeli } \\
\text { \& Bakker } \\
(2004)\end{array}$} \\
\hline Vigor & 3 & \\
\hline Dedication & 3 & \\
\hline Absorption & 3 & \\
\hline
\end{tabular}

The target population of this research consists of bank employees, who work for Greek banks, such as National Bank of Greece, Piraeus Bank, Eurobank, Alpha Bank, Attica Bank, etc, regardless their job position.

According to Hellenic Bank Association, the total number of personnel in banks in Greece was 37.734 at the end of year 2019 (HBA Member \& Associate Banks, 2019). During the data collection process (April and May of 2020), coronavirus pandemic was spread in Greece, causing hard limitations in work environments. 


\section{Ml Macrothink}

International Journal of Human Resource Studies

ISSN 2162-3058 2021, Vol. 11, No. 1

Hence, the questionnaire was uploaded online, via Google Forms and distributed on well-known online forums in social media with a total number of 4.223 members, in which bank employees are getting informed about the latest news of the banking sector in Greece and express their opinions related to their current job. Follow up posts were shared approximately two weeks after the initial post. $4,4 \%$ of the members joined the research, even though the questionnaire was uploaded in the group of Greek Federation of Bank Employees. After 3 weeks, 185 valid questionnaires were collected. It is noted that purposive sampling has been used since the research focuses on certain individuals who can provide important information that could not be found by any other sampling method.

\section{Results}

\subsection{Questionnaire Validity}

The questionnaire's validity was measured by Confirmatory Factor Analysis. Firstly, the Kaiser-Mayer-Olkin (KMO) indicator was used, which according to Fabrigar \& Wegener (2011) assesses the structure validity of the research factors. KMO values for all factors are higher than 0,60 (Table 2).

Secondly, Total Variance Explained (TVE) was measured. TVE explains what percentage of the total information included in all variables is represented by the factor (Henson \& Roberts, 2006). In this research, TVE score is more than $60,00 \%$ for most factors, while values marginally below $60,00 \%$ are still accepted, as it is shown in Table 2 .

Thirdly, loadings exceeding the minimum value of 0,60 show evidence of convergent validity. In this study, from the initial 22 items, 6 of them were excluded.

Finally, Cronbach's alpha was used in order to test the internal consistency of all factors. An acceptable reliability score is one that is 0,7 and higher (Heale \& Twycross, 2015). According to Table 2, all factors except one that were examined are reliable. Cronbach's $\alpha$ of two variables has values of 0,65 and 0,684 accordingly, which can be minimally accepted.

Table 2. Factor analysis

\begin{tabular}{|l|c|c|c|c|c|c|}
\hline & $\begin{array}{c}\text { Number of } \\
\text { items }\end{array}$ & $\begin{array}{c}\text { Items } \\
\text { excluded }\end{array}$ & KMO & TVE & $\begin{array}{c}\text { Factor } \\
\text { loadings }\end{array}$ & $\begin{array}{c}\text { Cronbach's } \\
\boldsymbol{\alpha}\end{array}$ \\
\hline $\begin{array}{l}\text { Perceived Training } \\
\text { Opportunities (PTO) }\end{array}$ & 4 & 1 & 0,604 & $59,124 \%$ & $0,61-0,84$ & 0,65 \\
\hline $\begin{array}{l}\text { Perceived Investment } \\
\text { in Employee } \\
\text { Development (PIED) }\end{array}$ & 9 & 4 & 0,845 & $60,159 \%$ & $0,63-0,78$ & 0,833 \\
\hline Work Engagement & 9 & 1 & 0,915 & $72,491 \%$ & $0,56-0,80$ & 0,944 \\
\hline
\end{tabular}

\subsection{Demographics}

The last section of the questionnaire contained questions asking the demographic 
characteristics of the employees who participated in the research. The demographic characteristics are presented in table 3 .

In total, 185 questionnaires were collected from Greek bank employees. The sample consists of a roughly equal number of male and female participants (42,7\% and 56,8\% respectively). Most participants are highly educated (34,6\% hold a university degree, 54,1\% a Master's degree, and $1,6 \%$ a $\mathrm{PhD}$ ). Moreover, participants are very experienced in banking services $($ mean $=3,36$; Std. Dev. $=1,049)$, with the majority of them working for more than 10 years in the banking sector.

Table 3. Demographic questions - Frequencies

\begin{tabular}{|c|c|c|c|c|}
\hline Demographic questions & & Frequency & Percent & Valid Percent \\
\hline \multirow{6}{*}{ Gender } & Male & 79 & $42,7 \%$ & $42,7 \%$ \\
\hline & Female & 105 & $56,8 \%$ & $56,8 \%$ \\
\hline & Prefer not to say & 1 & $0,5 \%$ & $0,5 \%$ \\
\hline & Total & 185 & $100 \%$ & $100 \%$ \\
\hline & Missing & 0 & $0,0 \%$ & \\
\hline & Total & 185 & $100 \%$ & \\
\hline \multirow{8}{*}{ Educational level } & Secondary School & 15 & $8,1 \%$ & $8,1 \%$ \\
\hline & Bachelor degree & 64 & $34,6 \%$ & $34,6 \%$ \\
\hline & Masters' degree & 100 & $54,1 \%$ & $54,1 \%$ \\
\hline & $\mathrm{PhD}$ & 3 & $1,6 \%$ & $1,6 \%$ \\
\hline & Other & 3 & $1,6 \%$ & $1,6 \%$ \\
\hline & Total & 185 & $100 \%$ & $100 \%$ \\
\hline & Missing & 0 & $0,0 \%$ & \\
\hline & Total & 185 & $100 \%$ & \\
\hline \multirow{7}{*}{ Years of working experience } & Less than 2 years & 22 & $11,9 \%$ & $11,9 \%$ \\
\hline & $2-5$ years & 14 & $7,6 \%$ & $7,6 \%$ \\
\hline & 5-10 years & 25 & $13,5 \%$ & $13,5 \%$ \\
\hline & More than 10 years & 124 & $67,0 \%$ & $67,0 \%$ \\
\hline & Total & 185 & $100 \%$ & $100 \%$ \\
\hline & Missing & 0 & $0,0 \%$ & \\
\hline & Total & 185 & $100 \%$ & \\
\hline
\end{tabular}




\section{Mll Macrothink}

International Journal of Human Resource Studies

ISSN 2162-3058

2021, Vol. 11, No. 1

The mean score of PTO was over the value of 3,0 indicating that banks offer rather moderate training to their employees. PIED had a mean score marginally below 3,0 indicating limited development opportunities in the banking industry. Generally speaking, participants in the banking sector believe that training and development is not placed at the heart of company policy. As for the variable work engagement, the answers were almost centralized in the middle of a 7-point scale (mean $=3,3669$ ). It could be argued, that most of the employees of our sample do not feel extremely engaged with their work.

Table 4. Mean scores - Factors

\begin{tabular}{|l|c|c|}
\hline & Mean & Std. Deviation \\
\hline Perceived training opportunities & 3,61 & 0,71804 \\
\hline $\begin{array}{l}\text { Perceived investment in employee } \\
\text { development }\end{array}$ & 2,92 & 0,81544 \\
\hline Work engagement & 3,36 & 1,37948 \\
\hline Vigor & 3,38 & 1,45306 \\
\hline Dedication & 3,32 & 1,48437 \\
\hline Absorption & 3,40 & 1,46320 \\
\hline
\end{tabular}

\subsection{Hypotheses Testing}

Correlation analysis was used in order to assess the relationships between the various factors of the study. More specifically, the Pearson's correlation coefficient was used. Through this method the existence of a possible relationship between two or more variables can be examined.

Consistent with the study's prediction correlation analysis indicates a significant relationship between the variables. According to Table 5, there is a positive relationship ( $\mathrm{r}=0.463$ ) between PTO and work engagement as well as a significant positive relationship $(r=0.642)$ with PIED and work engagement. In synopsis, results offer support for all research hypotheses (H1 and $\mathrm{H} 2)$.

These results indicate that positive perceptions about T\&D opportunities enhance employees' work engagement. It could be argued that banking organizations investing in T\&D practices may be able to effect employee's energy levels and enthusiasm because these practices may be perceived that their employer values them (through both training and development) and seem to signal an intent for long-term investment in employees (mainly through development practices). This essentially obliges them to reciprocate with discretionary role behaviour and contributions (Gong, Chang \& Cheung, 2010).

Table 5. Correlation analysis

\begin{tabular}{|l|l|c|c|c|}
\hline \multicolumn{2}{|c|}{} & $\begin{array}{c}\text { Perceived } \\
\text { training } \\
\text { opportunities }\end{array}$ & $\begin{array}{c}\text { Perceived investment } \\
\text { in employee } \\
\text { development }\end{array}$ & Work engagement \\
\hline $\begin{array}{l}\text { Perceived training } \\
\text { opportunities }\end{array}$ & $\begin{array}{l}\text { Pearson } \\
\text { Correlation }\end{array}$ & 1 & $0,680^{* *}$ & $0,479^{* *}$ \\
\hline
\end{tabular}




\begin{tabular}{|l|l|c|c|}
\hline $\begin{array}{l}\text { Perceived investment } \\
\text { in employee } \\
\text { development }\end{array}$ & $\begin{array}{l}\text { Pearson } \\
\text { Correlation }\end{array}$ & 1 & $0,657^{* *}$ \\
\hline Work engagement & $\begin{array}{l}\text { Pearson } \\
\text { Correlation }\end{array}$ & & 1 \\
\hline$* *$ Correlation is significant at the 0,01 level (2-tailed)
\end{tabular}

\section{Discussion}

\subsection{General Discussion}

T\&D practices are a special, complex and extremely interesting field of research for academics, managers, but also for employees in all sectors. Especially, these practices are valuable in companies in the service sector - such as banks. Banks, in order to maintain their competitive advantage in service quality and customer retention, are increasingly dependent on their employees. This empirical study tried to highlight the importance of providing T\&D opportunities in employees. The main objective of the present study was to assess the relationship between PTO, PIED and work engagement in the banking industry.

The present study was based on gaps that were recognized in the relevant literature (focus on employee perceptions in the service industry and on individual-level effects of HRM practices). In addition, it makes a distinction between training and development practices. In order to cover these research gaps, a literature review was conducted and a conceptual framework (research model) was developed, which investigated the relationships between perceptions of T\&D opportunities and work engagement. The conceptual framework was tested with the use of a structured questionnaire on a sample of Greek bank employees.

Empirical results revealed a significant relationship between PTO (H1), PIED (H2) and work engagement in the banking sector. This implies that bank employees who perceive training and development opportunities provided by their organizations positively, tend to see themselves as able to deal effectively with their job demands while maintaining a sense of emotional connection with their work activities. PIED seems to have a greater impact on work engagement signifying that long term, trust-based practices related to employee's professional development that can help employees build skills and further their career are perceived as a crucial engagement factor.

\subsection{Managerial Implications}

High levels of work engagement in the banking sector may promote retention of talent, foster service quality and customer loyalty. Talented professionals expect to work for an organization that will help them to build skills and knowledge and further their career. T\&D opportunities enhance the well-being of individual employees by producing benefits such as skill acquisition and career development. Banking organizations and managers that are willing to invest in human resources, and provide their employees opportunities to further and develop their skill will facilitate a felt obligation to reciprocate due to the way workers experience their work. T\&D may essentially cause positive employee attitudes and activity levels. Employees will perceive their work as something to which they really want to invest 
time, as a significant pursuit and as something on which they are fully concentrated.

Also, this study places high emphasis on how employees perceive T\&D practices rather than relying on accounts of intentions behind those practices as reported by HR professionals. Managers who wish to understand the effect of their HRM practices on employee behavior may conduct engagement workforce surveys to identify real needs and expectations. In the case of T\&D programs managers need to acknowledge the relevant influences of PTO and PIED on work engagement and contemplate how to provide them with the necessary programs they actually need and to support them with useful learning. Even a carefully planned training program may fail if management cannot convince participating employees of its value and relationship with their professional goals (Mondy and Martocchio, 2015).

It should also be noted, that even in uncertain times, like the Covid era, managers shouldn't ignore the importance of employee development. If they do, they risk decreasing morale by leaving talented employees perceiving like they are not valued by the organization. In the long term, poor workforce engagement will essentially lead to higher turnover, loosing these employees to competitors once the job market reenergizes.

\subsection{Limitations and Future Research}

This study is subject to a number of limitations. A main limitation of this study is the relevant small sample size as well as the data collection method (online groups of bank employees) due to the coronavirus pandemic spread in Greece. In this context, a possible generalization of the results should be avoided. Moreover, this study has concentrated on isolated HR practices like T\&D. Although these practices are proved to be crucial, they may not be comprehensive to define the nature of the exchange relationship. According to Gong et al., (2010), a social exchange relationship is not very likely to be fully initiated when training and development alone is provided. Future research may benefit from some of these limitations following a bigger sample approach as well as investigating more HR practices. Also, other research designs like experimental or longitudinal may verify the causal relationships among the different variables.

\section{References}

Alfes, K., Shantz, A. D., Truss, C., \& Soane, E. C. (2013). The link between human resource management practices, engagement and employee behaviour: a moderated mediation model", The International Journal of Human Resource Management, 24(2), 330-351. https://doi.org/10.1080/09585192.2012.679950

Amigo, I., Asensio, E., Menéndez, I., Redondo, S., \& Ledesma, J. A. (2014). Working in direct contact with the public as a predictor of burnout in the banking sector. Psicothema, 26(2), 222-6.

Bakker, A. B., \& Leiter, M. P. (2010). Work Engagement: A Handbook of Essential Theory and Research. Hove and New York, NY: Psychology Press. https://doi.org/10.4324/9780203853047

Benson, G. S., Finegold, D., \& Mohrman, S. A. (2004). You paid for the skills, now keep 
them: tuition reimbursement and voluntary turnover. Academy of Management Journal, 47(3), 315-31. https://doi.org/10.2307/20159584

Brown, A. L. (1994). The Advancement of Learning. Educational Researcher, 23(8), 4-12. https://doi.org/10.3102/0013189X023008004

CIPD (2013). Focus on rebuilding trust in the City, Employee outlook survey report summer 2013 , Retrieved

from: https://www.cipd.co.uk/Images/employee-outlook_2013-summer-rebuilding-trust_tcm18-960 4.pdf.

Crawford, E. R., LePine, J. A., \& Rich, B. L. (2010). Linking job demands and resources to employee engagement and burnout: A theoretical extension and meta-analytic test, Journal of Applied Psychology, 95(5), 834-848. https://doi.org/10.1037/a0019364

Cropanzano, R., \& Mitchell, M. S. (2005). Social exchange theory: An interdisciplinary review. Journal of Management, 31(6), 874-900. https://doi.org/10.1177/0149206305279602

Dachner, A. M., Ellingson, J. E., Noe, R. A., \& Saxton, B. M. (2019). The future of employee development, Human Resource Management Review, In Press. https://doi.org/10.1016/j.hrmr.2019.100732

Demerouti, E., \& Cropanzano, R. (2010). From thought to action: Employee work engagement and job performance, in: Bakker, A.B., Leiter, M.P. (Ed.), Work engagement: A handbook of essential theory and research (pp. 147-163), Psychology Press.

Dysvik, A., \& Kuvaas, B. (2008). The relationship between perceived training opportunities, work motivation and employee outcomes. International Journal of Training and Development, 12(3), 138-157. https://doi.org/10.1111/j.1468-2419.2008.00301.x

Dysvik, A., Kuvaas, B., \& Buch., R. (2016) Perceived investment in employee development and taking charge. Journal of Managerial Psychology, 31(1), 50-60. https://doi.org/10.1108/JMP-04-2013-0117

Fabrigar, R., \& Wegener, T. (2011). Exploratory Factor Analysis (Understanding Statistics). UK: Oxford University Press. https://doi.org/10.1093/acprof:osobl/9780199734177.001.0001

Gomez-Mejia, L. R., Balkin, D. B., \& Cardy, R. L. (2013), Managing Human Resources, $7^{\text {th }}$ edition, New Jersey: Pearson / Prentice Hall.

Gong, Y., Chang, S., \& Cheung, S.-Y. (2010). High performance work system and collective OCB: A collective social exchange perspective. Human Resource Management Journal, 20(2), 119-137. https://doi.org/10.1111/j.1748-8583.2010.00123.x

Grossman, R., \& Salas, E. (2011). The transfer of training: what really matters. International Journal of Training and Development, 15(2), 103-120. https://doi.org/10.1111/j.1468-2419.2011.00373.x

Gruman, J. A., \& Saks, A. M. (2011). Performance management and employee engagement. Human Resource Management Review, 21(2), 123-136. 
https://doi.org/10.1016/j.hrmr.2010.09.004

HBA Member \& Associate Banks (2019) Greek banking system structure / Branch network and number of employees. Retrieved from https://www.hba.gr/4Statistika/UplPDFs/2020/2019-BranchNetworkPersonnelData.pdf

Heale, R., \& Twycross, A. (2015). Validity and reliability in quantitative studies. Evidence-Based Nursing, 18(4), 66-67. https://doi.org/10.1136/eb-2015-102129

Henson, R. K., \& Roberts, J. K. (2006). Use of Exploratory Factor Analysis in Published Research: Common Errors and Some Comment on Improved Practice. Educational and Psychological Measurement, 66(3), 393-416. https://doi.org/10.1177/0013164405282485

Hughey, A. W., \& Mussnug, K. J. (1997). Designing effective employee training programmes. Training for Quality, 5(2), 52-57. https://doi.org/10.1108/09684879710167638

Jha, J. K., Pandey, J., \& Varkkey, B. (2019). Examining the role of perceived investment in employees' development on work-engagement of liquid knowledge workers: Moderating effects of psychological contract. Journal of Global Operations and Strategic Sourcing, 2(2), 225-245. https://doi.org/10.1108/JGOSS-08-2017-0026

Kahn, W. A. (1990). Psychological conditions of personal engagement and disengagement at work. Academy of Management Journal, 33(4), 692-724. https://doi.org/10.5465/256287

Kehoe, R. R., \& Wright, P. M. (2013). The impact of high performance human resource practices on employees' attitudes and behaviors. Journal of Management, 39, 366-391. https://doi.org/10.1177/0149206310365901

Kuvaas, B. (2008). An Exploration of How the Employee-Organization Relationship Affects the Linkage Between Perception of Developmental Human Resource Practices and Employee Outcomes. Journal of Management Studies, 45(1), 1-25.

Kuvaas, B., \& Dysvik, A. (2009). Perceived investment in employee development, intrinsic motivation and work performance. Human Resource Management Journal, 19(3), 217-236. https://doi.org/10.1111/j.1748-8583.2009.00103.x

Lee, C. H., \& Bruvold, N. T. (2003). Creating value for employees: Investment in employee development. The International Journal of Human Resource Management, 14(6), 981-1000. https://doi.org/10.1080/0958519032000106173

Lee, Y., Kwon, K., Kim, W., \& Cho, D. (2016). Work engagement and career: Proposing research agenda through a review of literature. Human Resource Development Review, 15, 29-54. https://doi.org/10.1177/1534484316628356

Ling, L., Qing, T., \& Shen, P. (2014). Can training promote employee organizational commitment? The effect of employability and expectation value. Nankai Business Review International, 5(2), 162-86. https://doi.org/10.1108/NBRI-09-2013-0034

Luthans, F., Avey, J. B., Avolio, B. J., \& Peterson, S. J. (2010). The Development and Resulting Performance Impact of Positive Psychological Capital. Human Resource 
Development Quarterly, 21(1), 41-67. https://doi.org/10.1002/hrdq.20034

Mauno, S., Kinnunen, U., \& Ruokolainen, M. (2007). Job demands and resources as antecedents of work engagement: A longitudinal study. Journal of Vocational Behavior, 70(1), 149-171. https://doi.org/10.1016/j.jvb.2006.09.002

Mondy, W. R. \& Martocchio, J. (2010). Human Resource Management, $14^{\text {th }}$ edition, Pearson, New Jersey.

McCauley, C. D., \& Hezlett, S. A. (2001). Individual development in the workplace, in: N. Anderson, D. S., Ones, H. K., Sinangil, \& Viswesvaran, C. (Ed.). Handbook of industrial, work \& organizational psychology (pp. 313-335). Sage Publications. https://doi.org/10.4135/9781848608320.n15

Nelissen, J., Forrier, A., \& Verbruggen, M. (2016). Employee development and voluntary turnover: Testing the employability paradox. Human Resource Management Journal, 27(1), 152-168. https://doi.org/10.1111/1748-8583.12136

Nishii, L. H., Lepak, D. P., \& Schneider, B. (2008). Employee Attributions of the "Why" of HR Practices: Their Effects on Employee Attitudes and Behaviors, and Customer Satisfaction. Personnel Psychology, 61, 503-545. https://doi.org/10.1111/j.1744-6570.2008.00121.x

Noe, R. A. (2013). Employee training and development. $6^{\text {th }}$ edition, McGraw-Hill, New York.

Pate, J., Martin, G., \& Staines, H. (2000). Exploring the relationship between psychological contracts and organizational change: A process model and case study evidence. Strategic Change, $9(8)$ 481-493. https://doi.org/10.1002/1099-1697(200012)9:8<481::AID-JSC513>3.0.CO;2-G

Rahman, W., \& Nas, Z. (2013). Employee development and turnover intention: theory validation. European journal of training and development, 37(6), 564-579. https://doi.org/10.1108/EJTD-May-2012-0015

Saks, A. M. (2006). Antecedents and consequences of employee engagement. Journal of Managerial Psychology, 21(7), 600-619. https://doi.org/10.1108/02683940610690169

Salanova, M., Agut, S., \& Peiró, J. M. (2005). Linking Organizational Resources and Work Engagement to Employee Performance and Customer Loyalty: The Mediation of Service

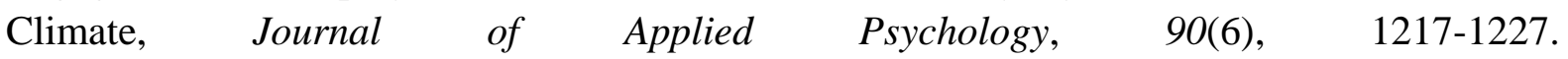
https://doi.org/10.1037/0021-9010.90.6.1217

Salas, E., Tannenbaum, S. I., Kraiger, K., \& Smith-Jentsch, K. A. (2012). The Science of Training and Development in Organizations: What Matters in Practice. Psychological Science in the Public Interest, 13(2), 74-101. https://doi.org/10.1177/1529100612436661

Salas, E., Wilson, K. A., Priest, H. A., \& Guthrie, J. W. (2006). Design, delivery, and evaluation of training systems, in Salvendy, G. (Ed.), Handbook of human factors and ergonomics (pp. 472-512), John Wiley \& Sons. https://doi.org/10.1002/0470048204.ch18

Schaufeli, W. B., \& Bakker, A. B. (2004). Job demands, job resources, and their relationship 
with burnout and engagement: A multi-sample study. Journal of Organizational Behavior, 25(3), 293-315. https://doi.org/10.1002/job.248

Sommerville, K. L. (2007). Hospitality Employee Management and Supervision: Concepts and Practical Applications. Hoboken, New Jersey: John Wiley \& Sons.

Sujatha, S., Chitra, M., Poonguzhali, \& Jahira, P. S. (2020). Antecedents on training and effectiveness among private and public sector banks in India. International Journal of Advanced Science and Technology, 29(3), 4180-4187.

Sweetman, D., \& Luthans, F. (2010). The power of positive psychology: psychological capital and work engagement, in: Bakker, A.B., \& Leiter, M.P. (Ed.), Work engagement: A handbook of essential theory and research (pp.54-68), Psychology Press.

Treven, S. J. (2003). International training: The training of managers for assignment abroad. Education \& Training, 45(8), 550-557. https://doi.org/10.1108/00400910310508937

Truitt, D. L. (2011). The Effect of Training and Development on Employee Attitude as It Relates to Training and Work Proficiency, SAGE Open, 1-13. https://doi.org/10.1177/2158244011433338

Truss, C., Alfes, K., Delbridge, R., Shantz, A., \& Soane, E. (2013). Employee Engagement in Theory and Practice. London and New York, NY: Routledge. https://doi.org/10.4324/9780203076965

Tsui, A. S., Pearce, J. L., Porter, L. W., \& Tripoli, A. M. (1997). Alternative Approaches to the Employee-Organization Relationship: Does Investment in Employees Pay Off?. Academy of Management Journal, 40(5), 1089-1121. https://doi.org/10.5465/256928

Wayne, S. J., Shore, L. M., \& Liden, R. C. (1997). Perceived Organizational Support and Leader-Member Exchange: A Social Exchange Perspective. The Academy of Management Journal, 4O(1), 82-111. https://doi.org/10.2307/257021

Wheeler, A. R., Halbesleben, J. R. B., \& Shanine, K. (2013). Exploring the middle range of person- environment fi $\mathrm{t}$ theories through a conservation of resources perspective, in A. L. Kristof-Brown \& J. Billsberry (Ed.), Organizational fi t: Key issues and new directions (pp. 170-194). Wiley. https://doi.org/10.1002/9781118320853.ch8

Xanthopoulou, D., Bakker, A. B., Demerouti, E., \& Schaufeli, W. B. (2009). Reciprocal relationships between job resources, personal resources, and work engagement. Journal of Vocational Behavior, 74(3), 235-244. https://doi.org/10.1016/j.jvb.2008.11.003

\section{Copyright Disclaimer}

Copyright for this article is retained by the author(s), with first publication rights granted to the journal.

This is an open-access article distributed under the terms and conditions of the Creative Commons Attribution license (http://creativecommons.org/licenses/by/4.0/). 